\begin{tabular}{c|c|c|c|c|c|c|c|} 
DOI: http://dx.doi.org/10.21276/ap.covid19.2021.10.1.11 \\
Annals of Phytomedicine: An International Journal \\
http://www.ukaazpublications.com/publications/index.php \\
Print ISSN : 2278-9839
\end{tabular}

\title{
The potential of herbal medicine from Kalimantan, Indonesia, to stimulate human immunity during the COVID-19 pandemic: A brief overview
}

\section{Rizki Maharani` and Andrian Fernandes}

Dipterocarps Research and Development Center, Research, Development and Innovation Agency (FOERDIA), Ministry of Environment and Forestry, Indonesia

Jl. A.W. Syahrani No. 68, Sempaja, Samarinda, East Kalimantan, Indonesia

\section{Article Info}

Article history

Received 1 April 2021

Revised 17 May 2021

Accepted 18 May 2021

Published Online 30 June 2021

\section{Keywords}

COVID-19

Body immunity

Eurycoma longifolia

Coscinium fenestratum

Eleutherine bulbosa

\begin{abstract}
The COVID-19 pandemic has occurred for more than a year. In the present, it is important to look for COVID-19 drugs to cure COVID-19 sufferers. However, increasing stamina or immunity is more important for everyone to prevent viruses or diseases from entering the body. Herbal remedies that are easy to find and easy to consume are an option to increase immunity. There are three herbal remedies that function to increase body immunity from Kalimantan, Indonesia, especially origin on Dipterocarps forest ecosystem, i.e., Pasak Bumi (Eurycoma longifolia Jack.), Akar Kuning (Coscinium fenestratum (Gaertn.) Colebr.) and Bawang Dayak (Eleutherine bulbosa (L.) Merr). The three medicinal plants are easily found in traditional markets and online shopping, and their function to increase the body's immunity.
\end{abstract}

\section{Introduction}

1.1 Potency of herbal medicine for body immunity

COVID-19 has become pandemic more than one year. Until now, the treatment of COVID-19 is still developing, it is necessary to look for alternative medicines (Yavuz and Ünal, 2020). It is crucial to search antiviral drugs from plants and other natural resources to end the COVID-19 pandemic immediately (Sytar et al., 2021).

Antiviral drugs used after symptom onset to reduce infectiousness to others by reducing viral shedding in the respiratory secretions of patients (Mitjà and Clotet, 2020). There are several potential antiviral mechanisms for COVID-19, i.e., fusion inhibitors, protease inhibitors, neuraminidase inhibitors, and M2 ion channel protein blockers (Frediansyah et al., 2021).

Besides looking for a cure for COVID-19, other steps that can take are using dietary therapy and herbal medicine to prevent COVID-19 (Panyod et al., 2020). Herbal medications can be used as another possibility treatment for COVID-19, to enhance the infection status of the respiratory and hepatobiliary systems, and research studies showed the antiviral effect (Kwoon et al., 2020). Herbal medicine has the potential to be used in increasing the body's immunity to prevent COVID-19 (Khanna et al., 2020). Herbal medicine had high potency as a reliable support for COVID-19 therapy (Grigore et al., 2020).

Corresponding author: Dr. Rizki Maharani

Dipterocarps Research and Development Center, Research, Development and Innovation Agency (FOERDIA), Ministry of Environment and Forestry, Indonesia

E-mail: rizma_annisa@yahoo.com, af.andrian.fernandes@gmail.com Tel.: +62 83140728159 and +62 541-206364

Copyright (c) 2021 Ukaaz Publications. All rights reserved.

Email: ukaaz@yahoo.com; Website: www.ukaazpublications.com
Increasing body immunity is very important to prevent the entry of viruses and diseases into the body. Therefore, it is necessary to carry out an inventory of herbal medicines that can increase the body's immunity that is easily found and easily consumed from the local area.

\section{Potency of herbal medicine origin Kalimantan, Indonesia for body immunity}

COVID-19 can attack all levels of society (Djalante et al., 2020), from the lower to the upper layers of society. A lot of people need herbal medicine to maintain body immunity (Babich et al., 2020). Herbal medicine must be easy to obtain, low prices and easy to consume (Builders, 2018). There are various kinds of herbal medicines, especially those derived from plants that are easily found in the Kalimantan, Indonesia, especially from Dipterocarp forest ecosystem. There are medicinal plants that function to maintain immunity when the COVID-19 outbreak occurs, i.e., Pasak Bumi (Eurycoma longifolia Jack.), Akar Kuning (Coscinium fenestratum (Gaertn.) Colebr., and Bawang Dayak (Eleutherine bulbosa (L.) Merr).

\subsection{Pasak Bumi (Eurycoma longifolia Jack.)}

Panjaitandan Zulfan (2015) revised with Panjaitan and Zulfan (2015) stated that one of the traditional medicinal plants from Indonesian forests is Pasak Bumi (Eurycoma longifolia Jack.). Pasak Bumi (E. longifolia) is a shrubby tree; leaves are pinnate in shape and green colour, in sandy soil (Rehman et al., 2016). Inflorescences are axillary panicles, pubescent with many small pedicellat evalvate flowers with 5-6 flower lobes (Lee et al., 2016).

The part of Pasak Bumi that is used traditionally is the root. However, advanced research was demonstrated that leaves also have been known to have potential as herbal medicine. In Kalimantan, 
Pasak Bumi is easily found in traditional markets and online shopping in several simplicial forms. Observation result of Pasak Bumi products on the market can be seen in the following Table 1 .

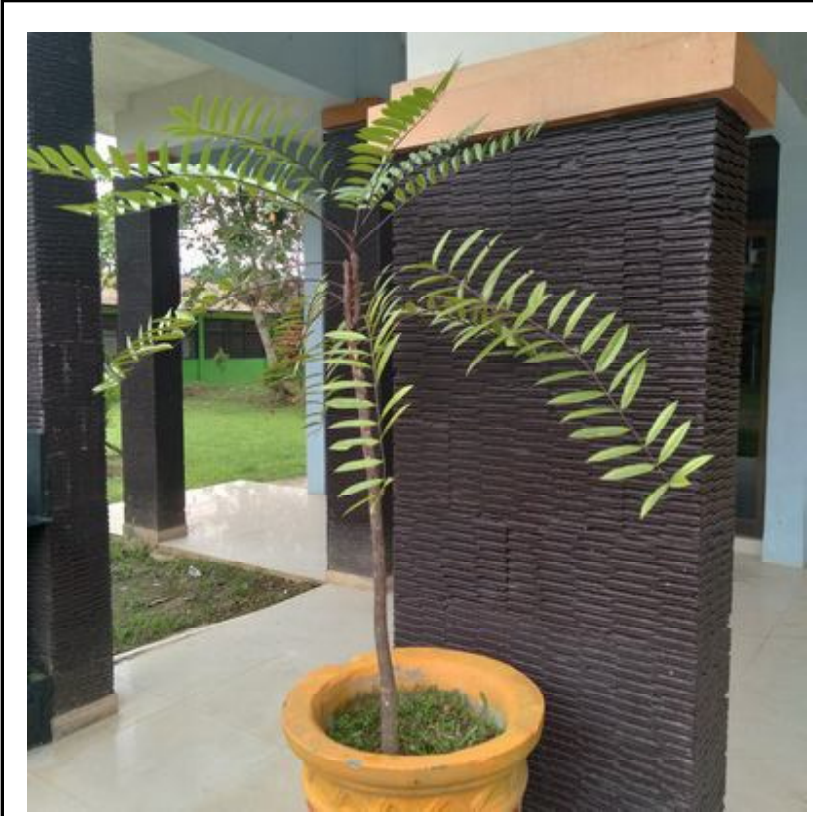

(a)

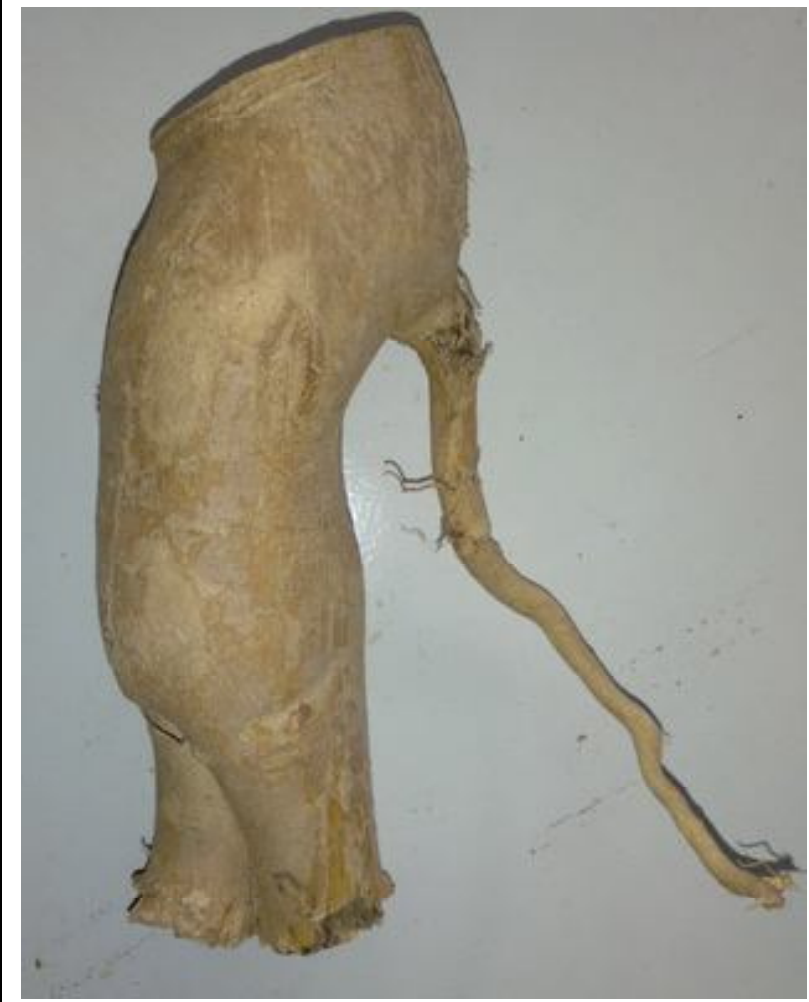

(b)

Figure 1: Pasak Bumi (Eurycoma longifolia Jack.). (a) Pasak Bum planted in pot for urban farming. (b) Pasak Bumi root. Photo by A. Fernandes
Table 1: Pasak Bumi products on the market

\begin{tabular}{|l|l|l|}
\hline Market types & Product type & \multicolumn{1}{|c|}{ Price } \\
\hline Traditional & Root & $50,000-60,000 \mathrm{IDR} / \mathrm{kg}$ \\
\hline market & root cut & $60,000-100,000 \mathrm{IDR} / \mathrm{kg}$ \\
& root powder & $100,000-150,000 \mathrm{IDR} / \mathrm{kg}$ \\
\hline On line & Root cut & $80,000-150,000 \mathrm{IDR} / \mathrm{kg}$ \\
shopping & Root shaving & $100,000-150,000 \mathrm{IDR} / \mathrm{kg}$ \\
& root powder & $125,000-200,000 \mathrm{IDR} / \mathrm{kg}$ \\
& $\begin{array}{l}\text { Root powder } \\
\text { capsule }\end{array}$ & $\begin{array}{l}50,000-100,000 \mathrm{IDR} / \mathrm{box} \\
50-100 \text { capsules } \\
\end{array}$ \\
& Root tea & $\begin{array}{l}15,000-50,000 \mathrm{IDR} / \mathrm{box} \\
10-20 \text { tea bags }\end{array}$ \\
& Root glass & $50,000-150,000 \mathrm{IDR} / \mathrm{glass}$ \\
\hline
\end{tabular}

Pasak Bumi (Eurycoma longifolia Jack.) had bitter taste (Abubakar et al., 2017). Pasak Bumi is sold in traditional markets and online stores in the form of dry roots that can be stored for a long time. Root storage requires a large space, so that it is made in the form of shavings or powder so as to save storage space. Buyers who do not like the bitter taste can choose a capsule form.

Pasak Bumi from Kalimantan forest is to increase body immunity that fight pathogen (Chabib et al., 2018). Pasak Bumi root extract has high antioxidant properties and contains alkaloids, flavonoids, steroids, terpenoids and tannins (Triawanti et al., 2020).



Figure 2: 2H-1-Benzopyran-2-one, 3-phenyl.

Major alkaloids found on root and stem organs were 3-Methyl-1oxo-2,3-dihydro-1H-pyrazolo [4,3-c][1,10] phenanthroline, and major terpenoid in root included 2H-1-Benzopyran-2-one, 3-phenyl(coumarin derivate), while in stem was Stigmasterol. (Rahmaia et al. 2011). 1-benzopyran-2-one is coumarin nucleus (Asif, 2015). 2H1-benzopyran-2-ones structure as coumarinderivates have been reported for antiviral, antioxidant, anti-inflammatory and other activity (Al-Majedy et al., 2016). Coumarin also serves as comparative immune-modulation (Abyshev and Nguyen, 2017). Phenanthrolines and its derivates have antiviral, antibacterial and antimicrobials properties (Čongrádyová et al., 2014). Penanthroline has methyl structure which is toxic to viruses (Margiotta et al., 2001). Stigmasterol as sterol has immune modulating activity (Navarro et al., 2001). 


\subsection{Akar Kuning (Coscinium fenestratum (Gaertn.) Colebr.)}

Root and stem of Akar Kuning (Coscinium fenestratum (Gaertn.) Colebr.) are medicinal plants in Kalimantan (Rinaldi et al., 2017). Akar Kuning (C.fenestratum) is woody climbing shrubs, cylindrical stem, yellowish-brown bark and yellowish woody tissue (Danapur et al., 2020). Leaves simple, alternate, broadly ovate, rounded, truncate or shallowly cordate at base, 10-32 $\times 8-22 \mathrm{~cm}$, 5-7 main nerves, with 2 pairs of distal lateral nerves (Tushar et al., 2008). The part of Akar Kuning used for treatment is the liana stem.

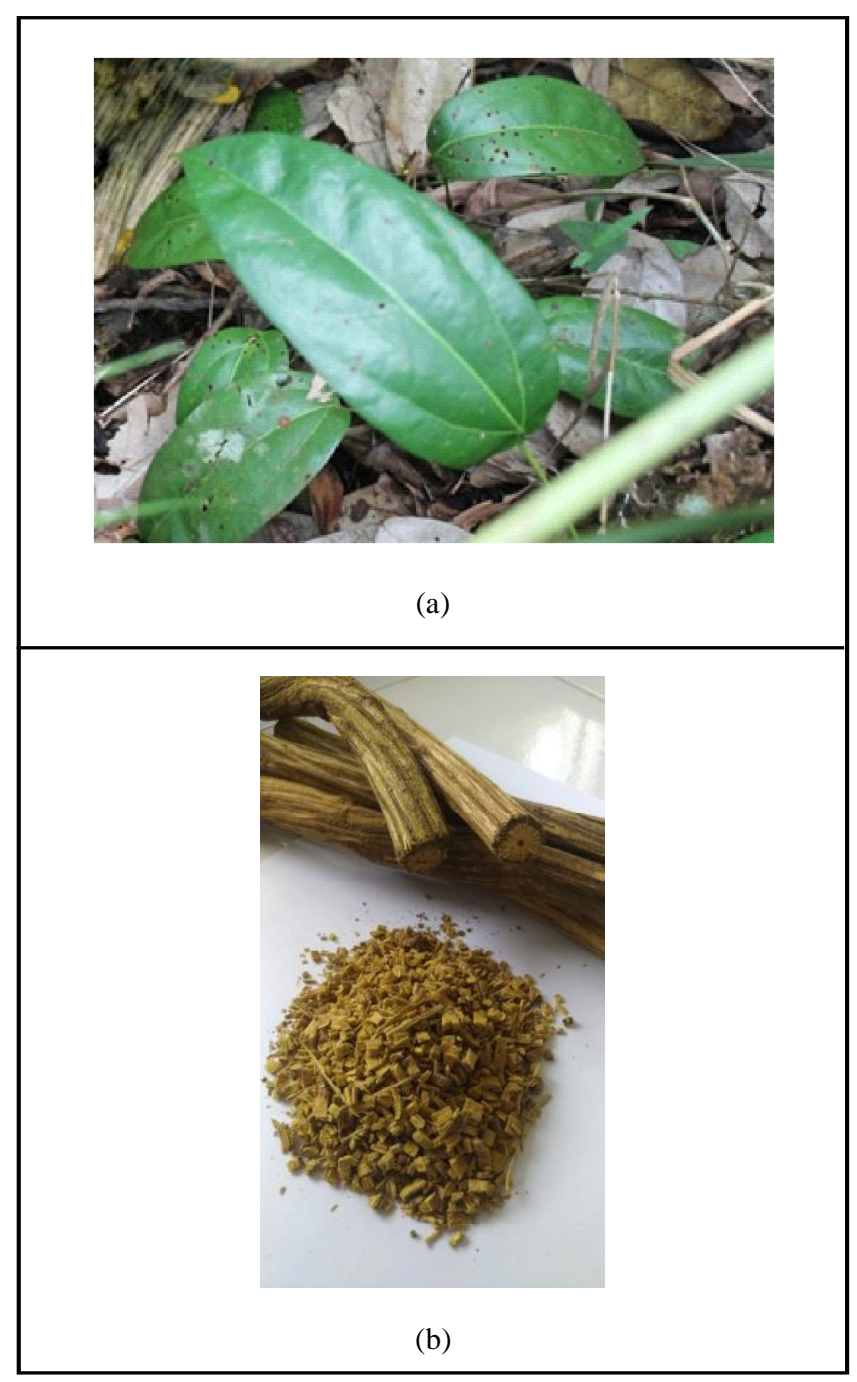

Figure 3: Akar Kuning (Coscinium fenestratum (Gaertn.) Colebr.). (a) Leaves, (b) Liana stem and powder. Photo by Noorcahyati.

Akar Kuning is classified as an endangered (Kashyap et al., 2016) and slow-growing species (Wilson et al., 2011). It must be wise and precise to harvest it. To harvest Akar Kuning, it is best to take the top of the stem, leave it apart from the bottom stem, and do not take the root for the conservation. In Kalimantan, the Akar Kuning is easily found in traditional markets and online shopping in several simplicia forms. Observation result of Akar Kuning products on the market can be seen in the following Table 2 .
Table 2: Akar Kuning products on the market

\begin{tabular}{|l|l|l|}
\hline Market types & Product type & \multicolumn{1}{|c|}{ Price } \\
\hline Traditional market & Stem cut & $60,000-150,000 \mathrm{IDR} / \mathrm{kg}$ \\
\hline On line shopping & Stem cut & $100,000-200,000 \mathrm{IDR} / \mathrm{kg}$ \\
& $\begin{array}{l}\text { stem cut } \\
\text { powder }\end{array}$ & $250,000-300,000 \mathrm{IDR} / \mathrm{kg}$ \\
& stem cut tea & $\begin{array}{l}40,000-75,000 \mathrm{IDR} / \mathrm{box} @ \\
25 \text { tea bags }\end{array}$ \\
\hline
\end{tabular}

Akar Kuning had acrid taste (Nayak et al., 2012). Akar Kuning sold in traditional markets and online stores have low moisture content, so it can be stored for a long time. To make it easier to consume, the online shop also sells Akar Kuning in the form of powder and herbal teas.

The stem of Akar Kuning has antimicrobial and the root is considered to be a bitter tonic (Rai et al., 2013). Akar Kuning is part of traditional medicine that is useful for increasing body immunity which can function as anti-inflammatory and antiviral; for example, for the treatment of cold (Kothalawala et al., 2020).

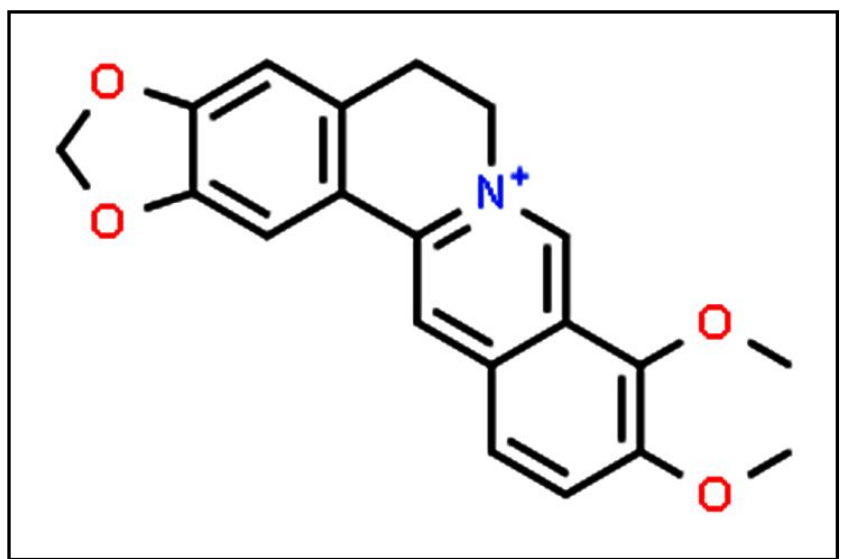

Figure 4: Berberine.

Akar Kuning contains berberine compounds which are classified as alkaloids (Potikanond et al., 2015). Berberine percentage in root tissue around $4.62 \%$ and in stem tissue $1.86 \%$ (Thriveni et al., 2017). Berberine reduces virus replication and it cantargets specific interactions between the virus and its host, which might be promising agents to fight against the current pandemic SARS-CoV-2 (Warowicka et al., 2020). Berberine has biological activity as immune stimulant (Neag et al., 2018).

\subsection{Bawang Dayak (Eleutherine bulbosa (L.) Merr)}

Bawang Dayak had scientific name, Eleutherine bulbosa (L.) Merr, E. american, E. subayphyla, E. citriodora, E guatemalensis, E. latifolia, E. longifolia, E. plicata and E. anomala. Bawang Dayak has been used for generations as folk medicine in Kalimantan (Harlita et al., 2018). Dayak tribes cultivated Bawang Dayak which had good adaptation capability to grow on various types of climate and soil (Febrinda et al., 2014). Bawang Dayak known as Bawang Tiwai, has bright red underground storage organs of bulb like onion, a pseudotrunked, green sword-shaped leaves which the base are pointed (Daryono et al., 2013). 


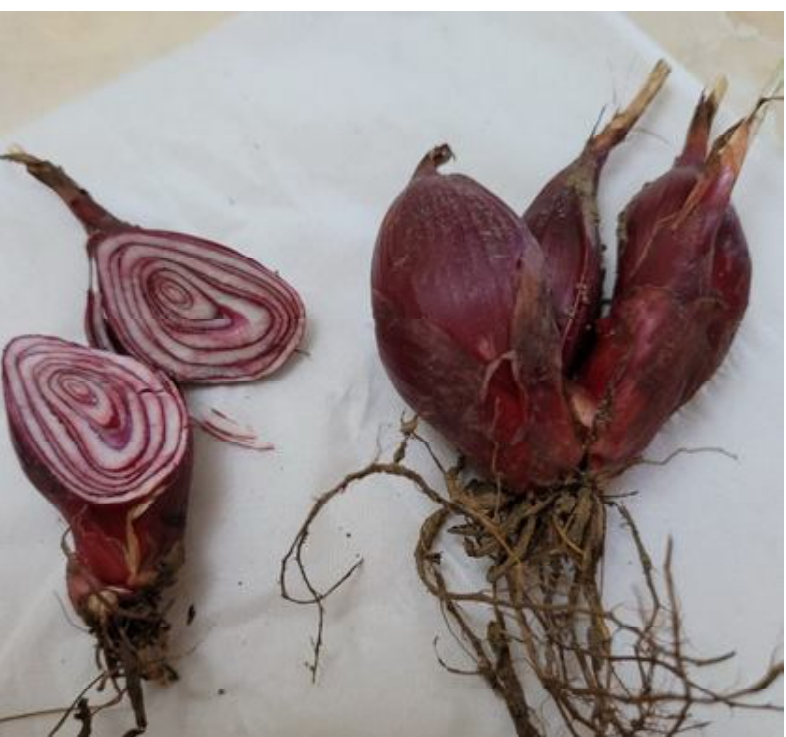

(a)

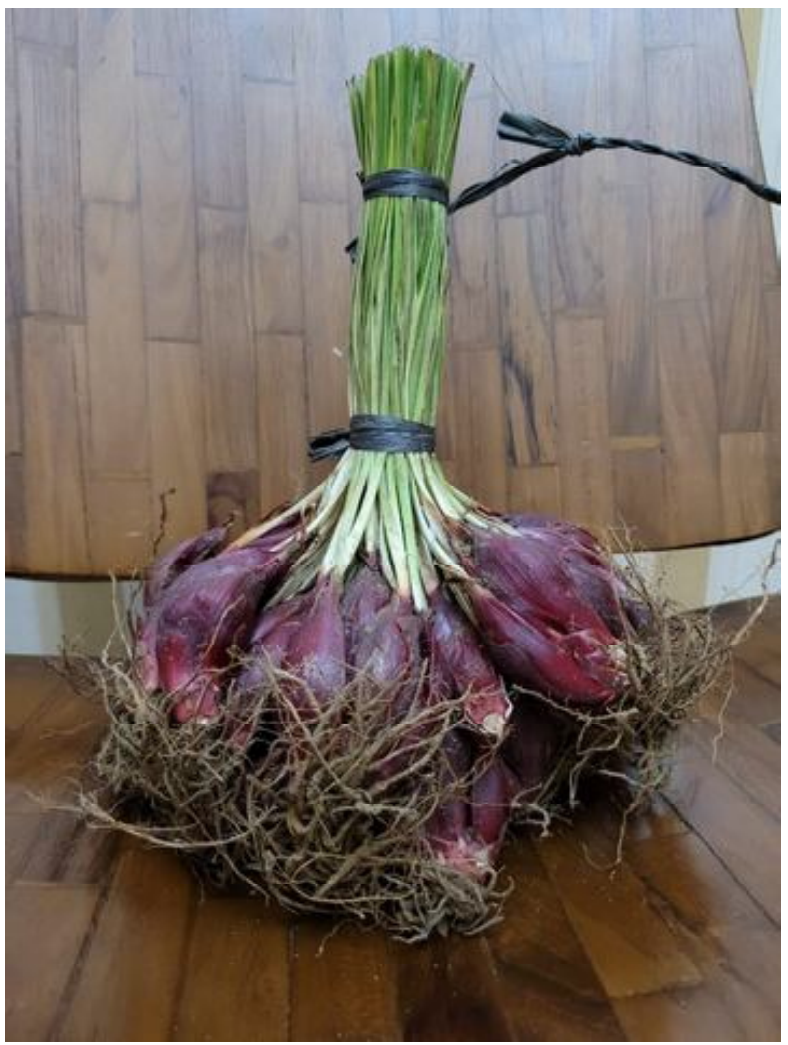

(b)

Figure 5: Bawang Dayak (a) Bawang Dayak underground storage organs of bulb like onion. (b) Bawang Dayak sold in the market. Photo by R. Maharani.

Observation result of Bawang Dayak products on the market can be seen in the following Table 3.
Table 3: Bawang Dayak products on the market

\begin{tabular}{|l|l|l|}
\hline Market types & Product type & Price \\
\hline Traditional market & Bulbs & $20,000-50,000 \mathrm{IDR} /$ bundle \\
\hline On line shopping & Bulbs & $30,000-50,000 \mathrm{IDR} / \mathrm{bundle}$ \\
& Bulbs shaving & $50,000-100,000 \mathrm{IDR} / \mathrm{kg}$ \\
& Bulbs powder & $100,000-200,000 \mathrm{IDR} / \mathrm{kg}$ \\
& Bulbs tea & $20,000-50,000 \mathrm{IDR} / \mathrm{box} @$ \\
& & 20 tea bags \\
\hline
\end{tabular}

Based on organoleptic test, Bawang Dayak had bitter taste (Muthia et al., 2021). Based on Table 3, Bawang Dayak sold in traditional markets are fresh so they cannot be stored for a long time. In online shops, Bawang Dayak is sold in the form of shavings, powder and herbal teas which have low water content, so they can be stored longer. The online store still provides fresh forms to be sold to buyers who want to boil fresh Bawang Dayak.

Bawang Dayak contain alkaloids, steroids, flavonoids, glycosides, saponins, triterpenoids, phenolics, tannins and quinones with some biological activities as immunostimulant, anti-inflammation, and others activities (Sesotyaning et al., 2019). Bawang Dayak also had high antioxidant activity (Kuntorini et al., 2016).

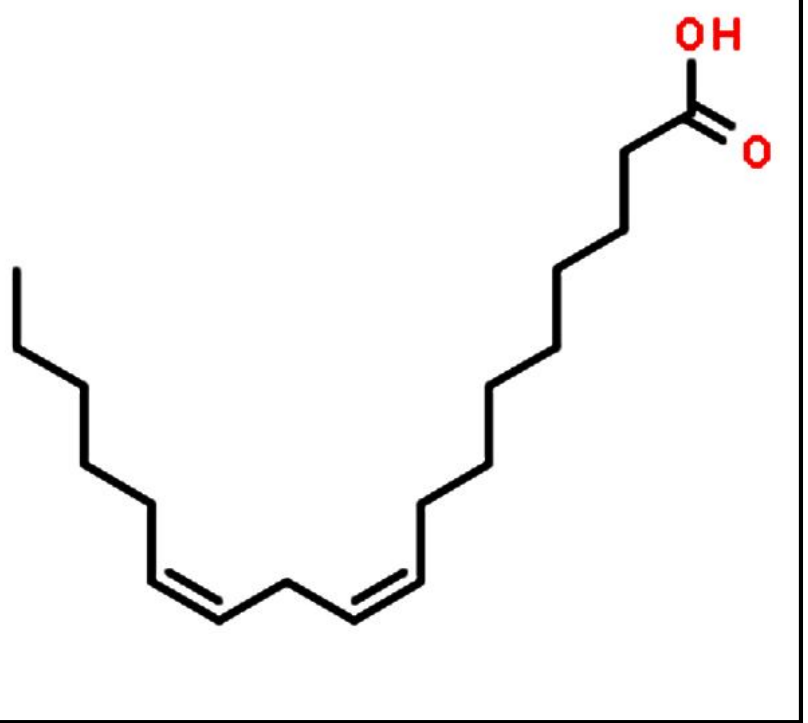

Figure 6: 9, 12-octadecadienoic acid.

GC-MS profile from chloroform extract of Bawang Dayak contains 9, 12-octadecadienoic acid or linoleic acid and 1-(2,3,5,6tetramethylphenyl) ethanone (Lestari et al., 2019), isoquinolines, xanthones, $2(1 \mathrm{H})$-Phenanthrenone, naphthalenes, and 2H-1benzopyran-2-one (Munaeni et al., 2019). Linoleic acid can promote immunity (Di Soto et al., 2018). Bawang Dayak had a potential as antiviral agent, because iso-eleutherine and isoeleutherol inhibited HIV replication, respectively (Insanu et al., 2014). Bawang Dayak contains bioactive naphtoquinone derivatives, which is usually used as antiviral, antimicrobial, antifungal, and antiparasitic agents (Kuntorini and Nugroho, 2010). 


\section{Conclussion}

There are medicinal plants that function to maintain human immunity from Kalimantan, Indonesia, especially from the Dipterocarp forest ecosystem during the COVID-19 pandemic, namely; Pasak Bumi (Eurycoma longifolia Jack.), Akar Kuning (Coscinium fenestratum (Gaertn.) Colebr.), and Bawang Dayak (Eleutherine bulbosa (L.) Merr). These three medicinal plants are easy to find in traditional markets with various standard prices, starting from 20,000 IDR in traditional markets, and starting from 30,000 IDR in online shops. Pasak Bumi and Bawang Dayak are easy to find, while Akar Kuning is classified as endangered species, the harvest is limited, therefore, Akar Kuning needs more efforts to supply market needs. Besides its easy to find in the market, these three medicinal plants are also easy to consume and communities widely believed to have benefits for increasing human immunity. However, this present study provided a brief information of the biological activities of these three medicinal plants as immune stimulants, and others general function probability for active drugs to handling the transmission of COVID-19 pandemic.

\section{Conflict of interest}

The authors declare that there are no conflicts of interest relevant to this article.

\section{References}

Abyshev, A.Z. and Nguyen, C.B. (2017). Synthetic covalently combined derivatives of 2H-1-Benzopyran-2-One. Drug development and Registration, (4):132-138.

Abubakar, B. M.; Salleh, F. M. and Wagiran, A. (2017). Chemical Composition of Eurycoma longifolia (Tongkat Ali) and the Quality Control of its Herbal Medicinal Products. Journal of Applied Sciences, 17(7): 324-338.

Al-Majedy, Y. K.; Kadhum, A. A. H.; Al-Amiery, A. A. and Mohamad, A. B. (2016) Coumarins: The antimicrobial agents. Systematic Reviews in Pharmacy, 8(1):62-70.

Asif, M. (2015). Overview of diverse pharmacological activities of substituted coumarins: Compounds with therapeutic potentials. Reviews, 1(1):1-16.

Babich, O.; Sukhikh, S.; Prosekov, A.; Asyakina, L., and Ivanova, S. (2020). Medicinal plants to strengthen immunity during a pandemic. Pharmaceuticals, 13(10):1-18.

Builders, P. F. (2018). Introductory chapter: Introduction to herbal medicine. Herbal Medicine, pp:1-9.

Chabib, L.; Muhtadi, W.K.; Rizki, M.I.; Rahman, R.A.; Suhendri, M.R., and Hidayat A. (2018). Potential medicinal plants for improve the immune system from Borneo Island and the prospect to be developed as nanomedicine. MATEC Web of Conferences, 154:1-6.

Čongrádyová, A.;Jomová, K.;Kucková, L.;Kožíšek, J.;Moncol', J. and Valko, M. (2014). Antimicrobial activity of copper(Ii) complexes. Journal of Microbiology, Biotechnology and Food Sciences, 10:67-70.

Danapur, V.; Haleshi, C. and Sringeswara, A.N. (2020). Endangered medicinal plant Coscinium fenestratum (Gaertn.) Colebr.: A review. Pharmacognosy Journal, 12(5):1077-1085.

Daryono, B.D.; Rahmadani, W.D. and Sudarsono. (2013). Identification of Bawang Sabrang (Eleutherine americana Merr. ex K. Heyne) in Indonesia based on chromosome characters. Indonesian Journal of Pharmacy, 24(1):22-29.
Di Sotto, A.; Vitalone, A. and Di Giacomo, S. (2018). Plant-derived nutraceuticals and immune system modulation: An evidence-based overview. Vaccines, 8(3):1-34.

Djalante, R.; Lassa, J.; Setiamarga, D.;Sudjatma, A.; Indrawan, M.; Haryanto, B.; Mahfud, C.;Sinapoy, M.S.; Djalante, S.;Rafliana, I.; Gunawan, L.A.; Surtiari, G.A.K., and Warsilah, H. (2020). Review and analysis of current responses to COVID-19 in Indonesia: Period of January to March 2020. Progress in Disaster Science, 6:100091.

Febrinda, A. E.; Yuliana, N. D.; Ridwan, E.; Wresdiyati, T. and Astawan, M. (2014). Hyperglycemic control and diabetes complication preventive activities of Bawang Dayak (Eleutherine palmifolia L. Merr.) bulbs extracts in alloxan-diabetic rats. International Food Research Journal, 21(4):1405-1411.

Frediansyah, A.; Tiwari, R.;Sharun, K.;Dhama, K., and Harapan, H. (2021). Antivirals for COVID-19: A critical review. Clinical Epidemiology and Global Health, 9:90-98.

Grigore, A.; Cord, D.; Tanase, C. and Albulescu, R. (2020). Herbal medicine, a reliable support in COVID therapy. Journal of Immunoassay and Immunochemistry, 41(6):976-999.

Harlita, T. D.; Oedjijono, and Asnani, A. (2018). The antibacterial activity of dayak onion (Eleutherine palmifolia (L.) merr) towards pathogenic bacteria. Tropical Life Sciences Research, 29(2):39-52.

Insanu, M.; Kusmardiyani, S. and Hartati, R. (2014). Recent studies on phytochemicals and pharmacological effects of Eleutherine americana Merr. Procedia Chemistry, 13:221-228.

Kashyap, S.; Kapoor, N. and Kale, R. D. (2016). Coscinium fenestratum callus and suspension cell culture of the endangered medicinal plant using vermicompost extract and coelomic fluid as plant tissue culture media. American Journal of Plant Sciences, 7(06):899-906.

Khanna, K.; Kohli, S. K.; Kaur, R.; Bhardwaj, A.; Bhardwaj, V.;Ohri, P.; Sharma, A.; Ahmad, A.; Bhardwaj, R. and Ahmad, P. (2020). Herbal immuneboosters: Substantial warriors of pandemic COVID-19 battle. Phytomedicine : International Journal of Phytotherapy and Phytopharmacology, 153361. Advance online publication.

Kothalawala, S. D.; Edward, D.; Harasgama, J.C.; Ranaweera, L.; Weerasena, O. V.D.S.J.; Niloofa, R.; Ratnasooriya, W.D.; Premakumara, G.A.S. and Handunnetti, S.M. (2020). Immunomodulatory activity of a traditional Sri Lankan concoction of Coriandrum sativum L. and Coscinium fenestratum $G$. evidence based complementary and alternative medicine, 2020.https://doi.org/10.1155/2020/9715060.

Kuntorini, E.M. and Nugroho, L.H. (2010). Structural development and bioactive content of red bulb plant (Eleutherine americana): A traditional medicines for local Kalimantan people. Biodiversitas Journal of Biological Diversity, 11(2):101-121.

Kuntorini, E.M.; Dewi, M. and Misrina. (2016). Anatomical structure and antioxidant activity of red bulb plant (Eleutherine americana) on different plant age. Biodiversitas, 17(1):229-233.

Kwoon, S.; Lee, W.; Jin, C.; Jang, I.; Jung, W.S.; Moon, S.K. and Cho, K. H. (2020). Could herbal medicine (Soshihotang) be a new treatment option for COVID-19? A narrative review. Integrative Medicine Research, 9(3): 100480 .

Lee, T.A.; Kamal, N.M.; Poay, T.H., and Roslan, I. (2016). Notes on morphological characteristics of eurycoma spp. and its status in peninsular Malaysia. Reinwardtia, 14(2):259.

Lestari, D.; Kartika, R.;Marlina, E., and Syamsul, E. S. (2019). Analisis fragmentasi GC-MS Senyawa Aktif Antikanker Leukimia Fraksi Kloro form Umbi Bawang Tiwai (Eleutherine bulbosa (Mill.) Urb). Jurnal Ilmiah Manuntung, 5(1): 1 . 
Margiotta, N.; Fanizzi, F. P.; Kobe, J., and Natile, G. (2001). Synthesis, characterisation and antiviral activity of platinum(II) complexes with 1,10-phenanthrolines and the antiviral agents acyclovir and penciclovir. European Journal of Inorganic Chemistry, 5:1303-1310.

Mitjà, O., and Clotet, B. (2020). Use of antiviral drugs to reduce COVID-19 transmission.The Lancet Global Health, 8(5):639-640.

Munaeni, W.; Widanarni, W.; Yuhana, M.; Setiawati, M., and Wahyudi, A. (2019). Phytochemical analysis and antibacterial activities of Eleutherine bulbosa (Mill.) Urb. extract against Vibrio parahaemolyticus. Asian Pacific Journal of Tropical Biomedicine, 9(9):397-404.

Muthia, R.; Wati, H.; Jamaludin, W. Bin, Kartini; Setiawan, F.; Fikri, M., and Wahhab, A. (2021). Standardization of Eleutherine bulbosaurb .bulbs and total flavonoid content from three locations in Kalimantan, Indonesia. Pharmacognosy Journal, 13(1):73-80.

Navarro, A.; De las Heras, B. and Villar, A. (2001). Anti-inflammatory and immune modulating properties of a sterol fraction from Sideritis foetens CLEM. Biological and Pharmaceutical Bulletin, 24(5):470-473.

Nayak, A.; Jasmin, S. R.; Padmavati, D. and Karthik, R. (2012). Chemistry and medicinal properties of Coscinium fenestratum (Gaertn.) Colebr (Tree Turmeric). Research J. Pharm. and Tech., 5(2):198-202.

Neag, M. A.; Mocan, A.; Echeverría, J.; Pop, R. M.; Bocsan, C. I.; Crisan, G. and Buzoianu, A. D. (2018). Berberine: Botanical occurrence, traditional uses, extraction methods, and relevance in cardiovascular, metabolic, hepatic, and renal disorders. Frontiers in Pharmacology, 9(AUG): $1-30$

Panjaitan, R.G.P. and Zulfan (2015). The effect of administration of Pasak Bumi (Eurycoma longifolia Jack.) roots to haematological profile of lactating mice. Indian Journal of Traditional Knowledge, 14(2): 231-235.

Panyod, S.; Ho, C.T. and Sheen, L. Y. (2020). Dietary therapy and herbal medicine for COVID-19 prevention: A review and perspective. Journal of Traditional and Complementary Medicine, 10(4):420-427.

Potikanond, S.; Chiranthanut, N.; Khonsung, P. and Teekachunhatean, S. (2015). Cytotoxic effect of Coscinium fenestratum on human head and neck cancer cell line (HN31). Evidence-Based Complementary and Alternative Medicine, 2015. https://doi.org/10.1155/2015/701939

Rahmalia, A. and Esyanti, R. R. (2011). A qualitative and quantitative evaluation of terpenoid and alkaloid in root and stem of Pasak Bumi (Eurycoma longifolia Jack). Jurnal Matematika and Sains, 16(1):49-52.
Rai, R.V.; Rajesh, P.S. and Kim, H.M. (2013). Medicinal use of Coscinium fenestratum (Gaertn.) Colebr.: An short review. Orient Pharm Exp. Med., 13:1-9.

Rinaldi, S.E.;Suryanto and Widuri, S.A. (2017). Informasi Perdagangan Akar Kuning di Pasar Tradisional Martapuradan Pasar Tradisional Rantau, Kalimantan Selatan. Jurnal Sains Dan Kesehatan, 1(8):434-439.

Rehman, S. U.; Choe, K., and Yoo, H. H. (2016). Review on a traditional herbal medicine, Eurycoma longifolia Jack (Tongkat Ali): Its traditional uses, chemistry, evidence-based pharmacology and toxicology. Molecules, 21(3).

Sesotyaning, N; Louisa, M.;Astuty, H.;Syafruddin, D. and Asih, P. B. S. (2019). In vitro antimalarial potency of Eleutherine bulbosa and its effect on the morphology of Plasmodium falciparum. International Journal of Applied Pharmaceutics, 11(1):172-176.

Yavuz, S., and Ünal, S. (2020). Antiviral treatment of covid-19. Turkish Journal of Medical Sciences, 50(1):611-619.

Sytar, O.; Brestic, M.; Hajihashemi, S.; Skalicky, M.; Kubeš, J.; Lamilla-Tamayo, L.; Ibrahimova, U.; Ibadullayeva, S., and Landi, M. (2021). COVID-19 prophylaxis efforts based on natural antiviral plant extracts and their compounds. Molecules, 26(3):727.

Triawanti; Sanyoto, D.D. and Noor, M. S. (2020). The supplementation of Pasak Bumi (Eurycoma longifolia Jack.) in undernourished rats to increase spatial memory through antioxidant mechanism. Clinical Nutrition Experimental, 33:49-59.

Thriveni, H.N.; Ramesh Babu, H.N. and Vasudeva, R. (2017). Patterns of accumulation of berberine alkaloid and chemical profiling of natural populations of Coscinium fenestratum (Menispermaceae) in the central Western Ghats, India. Indian Journal of Natural Products and Resources, 8(3):240-247.

Tushar, K. V.; George S.;Remashree, A.B., and Balachandran, I., (2008). Coscinium fenestratum (Gaertn.) Colebr: A review on this rare critical endangered and highly-traded medicinal plants. Journal of Plants Sciences, 3(2):133-145.

Warowicka, A.;Nawrot, R., and Goździcka-Józefiak, A. (2020). Antiviral activity of berberine. Archives of Virology, 165(9):1935-1945.

Wilson, G. S.; Madtha, R.; Kiran Nivas, S. and D'Souza, L. (2011). Isolation of endophytic fungi from Coscinium fenestratum : A red listed endangered medicinal plant. Eur. Asian Journal of Biosciences, 53: $48-53$.

Rizki Maharani and Andrian Fernandes (2021). Potency of herbal medicine origin Kalimantan, Indonesia, to increase body immunity during COVID-19: A brief overview. Ann. Phytomed., Volume10, Special Issue1 (COVID-19): S115-S120. http://dx.doi.org/10.21276/ap.covid19.2021.10.1.11 